\title{
Pesan Dakwah pada Upacara Adat Ngeuyeuk Seureuh
}

\author{
Zazam Khairul Umam ${ }^{1 *}$, Karsidi Diningrat ${ }^{1}$, dan Asep Iwan \\ Setiawan $^{2}$ \\ ${ }^{1}$ Jurusan Komunikasi dan Penyiaran Islam, Fakultas Dakwah dan Komunikasi, \\ UIN Sunan Gunung Djati, Bandung \\ 2Jurusan Manajemen Dakwah, Fakultas Dakwah dan Komunikasi, \\ UIN Sunan Gunung Djati, Bandung \\ *Email : zazam.khairul.umam@gmail.com
}

\begin{abstract}
ABSTRAK
Penelitian ini untuk mengetahui bentuk upacara adat Ngeuyeuk Seureuh, dan pesan-pesan dakwah yang terdapat dalam upacara adat tersebut di Kampung Palintang Desa Cipanjalu Kecamatan Cilengkrang Kabupaten Bandung. Adapun rumusan masalah dalam penelitian ini adalah Bagaimana bentuk atau cara upacara adat Ngeujeuk Seureub dan pesan dakwah pada upacara adat Ngeuyeuk Seureuh. Metode yang digunakan adalah metode deskriptif, yaitu menyajikan gambaran lengkap mengenai kehidupan sosial dan fenomena terhadap upacara adat Ngeuyeuk. Seureub di Kampung Palintang. Berdasarkan hasil penelitian upacara adat Ngeuyenk Seureuh merupakan suatu rangkaian tradisi pada upacara pernikahan di tatar Sunda yang telah dilaksanakan secara turun-temurun. Tradisi ini biasanya dilaksanakan satu hari sebelum hari pernikahan di rumah calon mempelai wanita pada pagi hari atau malam hari. Dalam upacara adat Ngenyeuk Seureuh ini terdapat pesan-pesan dakwah Islam yang terbagi menjadi dua yaitu pesan dakwah verbal dan non verbal. Pesan dakwah verbal yang terkandung dalam upacara adat Ngeuyenk Seureuh diambil berdasarkan Alquran dan hadis, sedangkan pesan dakwah non verbal terdapat pada semua bagian media upacara adat Ngenyeuk Seureuh.
\end{abstract}

Kata Kunci : pesan dakwah; upacara adat; ngeuyeuk seureuh.

\section{ABSTRACT}

This study is to know the form of traditional ceremony Ngeuyenk Seureuh, and the messages of da'wah contained in the ceremony in the village of Palintang Village Cipanjalu Village District Cilengkrang Bandung. The formulation of the problem in 
this research is how the form or way of traditional ceremony Ngeuyeuk Seureub and the message of dakwah at traditional ceremony Ngeuyenk. Seureub. The method used is descriptive method, which presents a complete picture of social life and phenomenon of traditional ceremony Ngeuyeuk Seureub in Kampung Palintang. Based on the results of research, has obtained the result that the traditional ceremony Ngeuyeuk. Seureuh is a series of traditions at the wedding ceremony in tatar Sunda which has been implemented for generations. This tradition is usually beld one day before the wedding day at home of the bride in the morning or evening. In the traditional ceremony Ngeuyeuk Seureuh there are messages of Islamic propaganda. The message of Da'wah in Ngeuyeuk. Seureub traditional ceremony is divided into two namely verbal and non verbal message of da'wah. The message of verbal da'wah contained in traditional ceremony Ngeuyeuk Seureub is taken based on al-qur'an and hadith, while non verbal message of dakwah is found in all parts of traditional ceremony media Ngeuyeuk Seureuh.

Keywords : message of da'wah; traditional ceremonies; ngeuyeuk seureuh.

\section{PENDAHULUAN}

Dakwah merupakan bagian dari tugas suci (ibadah) umat Islam. Apapun bentuknya dan konteksnya, akan dibutuhkan oleh umat dalam menumbuhkan dan mewujudkan kesalehan individual dan kesalehan sosial, yaitu pribadi yang memiliki kasih sayang terhadap sesamanya dan mewujudkan tatanan masyarakat marhamah yang dilandasi oleh kebenaran tauhid, persamaan derajat, semangat persaudaraan kesadaran akan arti penting kesejahteraan bersama dan penegakan keadilan di tengah-tengah kehidupan masyarakat (Sa'diah, 2015: 125).

Maka dari itu dakwah sangat perlu untuk dilakukan. Adapun berbagai metode dakwah yang dapat dilakukan saat ini seperti melalui media cetak, internet atau bahkan melalui budaya yang seperti dilakukan oleh Walisongo masalalu silam.

Salah satu dari Walisongo yang berdakwah menggunakan metode yang memadukan unsur Islam dengan budaya lokal adalah Sunan Kalijaga. Beliau termasuk salah seorang wali yang produktif menciptakan tembang dan juga cerita-cerita wayang, yang selanjutnya dijadikan sebagai salah satu media dalam berdakwah. Selain itu beliau juga mengenalkan "pakaian takwa", mengadakan pertunjukkan seni dalam memperingati maulud Nabi yang dikenal dengan sebutan grebeg maulud, upacara sekatenan (pengucapan dua kalimat syahadat) yang dilakukan setiap tahun mengajak orang jawa masuk Islam (Arifin: 2010:851). 
Penelitian yang serupa dengan judul "Tradisi Ngeuyeuk Seureub Sebagai model Tabligh". Dilakukan oleh Fenti Effendy, dari Universitas Islam Negeri Sunan Gunung Djati Bandung. Perbedaan dengan penelitian ini yaitu penelitian yang dilakukan oleh Fenti Effendy terfokus pada Ngeuyeuk Seureuh sebagai Model Tabligh, sedangkan penulis meneliti fokus terhadap Pesan Dakwah pada upacara adat Ngeuyeuk Seureuh.

Dilihat dari sudut bahasa Indonesia, kebudayaan berasal dari bahasa sansekerta "buddhayah", yaitu bentuk jamak dari budi atau akal. Pendapat lain mengatakan, bahwa "budaya" adalah sebagai suatu perkembangan dari kata majemuk budi-daya, yang berarti daya dari budi, karena itu mereka membedakan antara budaya dengan kebudayan. Budaya adalah daya dari budi yang berupa cipta, karsa, dan rasa, dan kebudayaan adalah hasil dari cipta, karsa dan rasa tersebut (Widagho, 1994 : 18).

Adapun menurut Soerjanto Poespowardojo , budaya secara harfiah berasal dari bahasa laitin, yaitu colere yang memiliki arti mengerjakan tanah, mengolah, dan memelihara. Adapun menurut istilah, kebudayaan merupakan sesuatu yang agung dan mahal karena tercipta dari hasil rasa, karya, karsa, dan cipta manusia yang keluar dari akal budi manusia, dan semua itu merupakan sifat yang hanya ada pada manusia. Tidak ada mahluk lain yang memiliki anugrah itu sehingga ia merupakan sesuatu yang agung dan mahal. Oleh karena itu, Koentjaningrat berpendapat bahwa budaya adalah keseluruhan sistem, gagasan, tindakan, dan hasil karya manusia dalam rangka kehidupan masyarakat yang dijadikan sebagai milik diri manusia dengan cara belajar (Gustini dan Alfan, 2012 :16).

Manusia adalah kunci perubahan dalam lingkungannya, karena manusia dan tingkahlakunya mampu mempengaruhi kelangsungan hidup seluruh mahluk yang lain. Akan tetapi, melalui lingkungannya ini pula, tingkahlaku manusia ditentukan, sehingga sebenarnya ada hubungan timbal balik yang seimbang antara manusia dan lingkungannya. Oleh karena itu, agar harmonisasi kehidupan ini tercipta dan tetap terjaga, manusia harus bersikap dan berperilaku arif terhadap lingkungan.

Kearifan terhadap lingkungan menurut Nurma Ali Ridwan, dapat dilihat dari perlakuan manusia terhadap benda-benda, tumbuhan, hewan, dan apapun yang ada disekitarnya (Gustini dan Alfan, 2012 :66-67).

Kearifan lokal atau sering disebut local wisdom dapat dipahami sebagai usaha manusia dengan menggunakan akal budinya (kognisi) untuk bertindak dan bersikap terhadap sesuatu, objek, atau perisitiwa yang terjadi dalam ruang tertentu. Pengertian ini disusun secara etimologi, yaitu 
wisdom dipahami sebagai kemampuan seseorang dalam menggunakan akal pikirannya dalam bertindak atau bersikap, sebagai hasil penilaian terhadap sesuatu, objek, atau peristiwa yang terjadi. Sebagai sebuah istilah, wisdom sering diartikan sebagai "kearifan atau kebijaksanaan".

Lokal, secara spesifik menunjuk pada ruang interaksi terbatas dengan sistem nilai yang terbatas pula, yaitu ruang interaksi yang sudah di desain sedemikian rupa, yang didalamnya melibatkan pola antarmanusia dan antar manusia dengan lingkungan fisiknya (Gustini dan Alfan, 2012 :67-68).

Upacara adat Ngenyenk Seureuh adalah sebuah wasiat atau pesan yang disampaikan melalui benda-benda atau media oleh pangeuyeuk kepada kedua mempelai. Sedangkan kata Ngeuyeuk Seureub berasal dari paheuyeukheuyeuk yang berarti mengolah atau mengatur rumah tangga. Maksud dan tujuan dari upacara adat Ngenyenk. Seureuh yaitu untuk memberikan pepeling atau nasihat kepada kedua calon mempelai, selain itu Ngenyeuk. Seureub juga dipercaya sebagai pengikat tali batin antara kedua mempelai.

Menurut tokoh adat di Kampung palintang yaitu Yuyu, Ngeuyenk. Seureuh sebenarnya adalah dakwah, tetapi terdapat perbedaan dengan dakwah pada umumnya yaitu dakwah yang dilakukan adalah menyampaikan makna dan maksud dari benda-benda yang ada pada media upacara adat Ngenyenk Seureuh. Menurutnya upacara adat Ngeuyeuk Seureuh di Kampung Palintang sudah ada sejak tahun 1800-an. Upacara ini dibawa ke Kampung Palintang oleh Bapak Ruba'I, beliau adalah tokoh adat di Kampung Palintang. Sejak datangnya adat Ngeuyeuk Seureuh, masyarakat di Kampung Palintang tidak ada yang menolak, karena menurut masyarakat di Kampung Palintang upacara adat Ngeuyeuk. Seureuh memiliki nilai-nilai yang sangat baik, selain itu sebagian masyarakat di Kampung Palintang menganggap bahwa pernikahan belum sah jika tidak melaksanakan upacara adat Ngeuyeuk Seureuh, maksudnya menikah tidak cukup secara lahiriyah saja tetapi juga harus batinniyah.

Pelaksanaan upacara adat Ngeuyeuk. Seureub kata Yuyu biasanya dilaksanakan sehari sebelum akad nikah di rumah mempelai perempuan, waktu pelaksanaanya sore hari atau malam hari. Upacara adat Ngeuyeuk Seureub dihadiri oleh kedua keluarga mempelai dan ketua adat. Tidak ada batasan bagi siapapun yang ingin menghadiri upacara adat Ngeuyeuk. Seureuh selama tidak menganggu pada saat pelaksanaan (Wawancara : Yuyu. Kamis 19 Maret 2017).

Dalam upacara adat Ngeuyenk Seureub terdapat alat-alat atau benda 
yang digunakan sebagai media pesan. Alat-alat atau benda tersebut adalah Samak, golok, benang dan masih banyak lagi.

Lokasi penelitian dilakukan terhadap upacara adat Ngeuyeuk Seureub di kampung Palintang Desa Cipanjalu Kecamatan Cilengkrang Kabupaten Bandung. Alasan memilih lokasi ini karena data yang dibutuhkan tersedia dan lokasi penelitian terjangkau sehingga dapat menghemat waktu, biaya, dan tenaga.

Berdasarkan latar belakang yang telah dipaparkan di atas, dapat dirumuskan bahwa inti dari permasalahan yang akan di analisis dalam penelitian ini adalah: 1) Bagaimana bentuk atau cara upacara adat Ngeuyeuk Seureuh di Kampung Palintang Desa Cipanjalu Kecamatan Cilengkrang Kabupaten Bandung?; dan 2) Bagaimana pesan dakwah pada upacara adat Ngeuyeuk Seureub di Kampung Palintang Desa Cipanjalu Kecamatan Cilengkrang Kabupaten Bandung?

Metode yang digunakan dalam penelitian ini adalah metode deskriptif yaitu suatu rumusan masalah yang memandu penelitian untuk mengeksplorasi atau memotret situasi sosial yang akan diteliti secara menyeluruh luas dan mendalam (Sugiono, 2007: 209). Sehingga dari metode yang digunakan dapat dipaparkan dengan jelas seputar upacara adat Ngeuyeuk Seureub dan pesan dakwah yang ada di dalamnya.

\section{LANDASAN TEORITIS}

Teori yang akan dijadikan landasan dalam penelitin ini adalah teori Interaksi Simbolik menurut George Herbert Mead. Selain itu dalam landasan teoritis ini juga akan dibahas mengenai pesan, dakwah, dan adat atau budaya.

Pesan yaitu apa yang dikomunikasikan oleh sumber kepada penerima. Pengertian ini berdasarkan pada lima unsur komunikasi laswell yang salah satunya adalah pesan, pesan merupakan seperangkat simbol verbal dan atau non verbal yang mewakili perasaan, nilai, gagasan, atau maksud sumber tadi. Pesan mempunyai tiga komponen: makna, simbol, yang digunakan untuk menyampaikan makna, dan bentuk organisasi pesan. Pesan dalam Kamus Besar Bahasa Indonesia (2007:865) memiliki arti perintah, nasihat, permintaan amanat, yang disampaikan orang lain.

Menurut Wilbur Schramm dalam Tasmara (1997: 7) pesan adalah ide-ide atau gagasan atau buah fikiran yang disampaikan oleh sumber kepada orang lain dengan tujuan agar orang lain bertindak sama sesuai 
dengan harapan yang dituangkan dalam pesan tersebut. Pesan-pesan komunikator disampaikan melalui simbol-simbol yang bermakna kepada penerima pesan.

tentunya memiliki tujuan yang diharapkan bisa tersampaikan dari komunikator kepada komunikan. Adapun tujuan pesan tersebut diantaranya adalah: 1) Pesan yang dirancang dan disampaikan sedemikian rupa sehingga menarik perhatian komunikan; 2) Pesan yang menggunakan lambang-lambang. Lambang itu berkaitan dengan pengalaman yang sama antara komunikator dengan komunikan; 3) Pesan yang membangkitkan kebutuhan pribadi komunikan serta menyarankan cara-cara untuk memperoleh kebutuhan tersebut; dan 4) Pesan yang menyarankan langkah-langkah yang disesuaikan dengan situasi kelompok komunikan.

Sedangkan tujuan pesan menurut Jalalludin Rakhmat (2005: 23) dalam bukunya Metodelogi Komunikasi, tujuan umum dari pesan yaitu: 1) Memberitahukan (informatif) yakni tujuannya untuk menambah pengetahuan pendengaran dan diharapkan memperoleh penjelasan, menurut minat yang memiliki pengertian tentang persoalan yang dibicarakan; 2) Mempengaruhi (persuasif) yakni tujuannya agar orang mempercayai sesuatu, melakukannya atau terbakar semangatnya dan antusiasmenya. Keyakinan tindakan dan semangat dalah bentuk reaksi yang diharapkan; dan 3) Menghibur (rekreatif) yakni tujuannya agar reaksi pendengar yang diharapkan lebih perhatian, senang dan terhibur dengan humor.

Berdasarkan penjelasan di atas, maka dapat disimpulkan bahwa pesan merupakan suatu agagasan atau fikiran yang disampaikan oleh komunikator kepada komunikan dengan harapan komunikan dapat sepaham dengan apa yang dituangkan di pesan tersebut. Pesan juga mempunyai tiga komponen yaitu makna, simbol, yang digunakan untuk menyampaikan makna, dan bentuk organisasi pesan.

Selain itu, tentunya pesan juga memiliki tujuan. Tujuan tersebut adalah memberikan informasi kepada komunikan, menghibur komunikan, dan mempengaruhi komunikan. Ketiga hal ini sangat berkaitan atau sangat dibutuhkan dalam kegiatan dakwah, khususnya untuk mencapai keberhasilan dakwah.

Ditinjau dari segi bahasa "Da'wah" berarti : panggilan, seruan atau ajakan. Bentuk perkataan tersebut dalam bahasa Arab disebut mashdar. Sedangkan bentuk kata kerja (Fi’i)nya adalah berarti : memanggil, menyeru, atau mengajak (Da'a, Yad'u, Da'watan). 
(Saputra, 2012: 1).

Secara sederhana, dakwah dapat dirumuskan sebagai "suatu proses internalisasi, transmisi, difusi, institusionalisasi, dan transformasi Islam yang melibatkan usnur da'i, pesan, media, metode, mad'u, tujuan, dan respon serta dimensi ruang dan waktu untuk mewujudkan kehidupan yang khasanah, salam, nur, di dunia dan akhirat (Safei, 2003 : 119).

Dakwah dapat pula diartikan sebagai upaya terus-menerus untuk melakukan perubahan pada diri manusia menyangkut pikiran (Fikrah), perasaan (Syu'ur), dan tingkah laku (suluk) yang membawa mereka kepada jalan Allah (Islam), sehingga terbentuk sebuah masyarakat islami (almujtama' al-Islam) (M.Romli, 2003: 6).

Dalam kegiatan dakwah, terdapat beberapa unsur yang tentunya berhubungan antara satu unsur dengan unsur yang lainnya. Unsur-unsur dalam kegiatan dakwah diantaranya adalah: 1) da'i (Subjek Dakwah; 2) mad'u (Objek Dakwah); 3) Maudhu ad-Dakwah (Pesan Dakwah); 4) Uslub ad-Dakwah (Metode Dakwah); dan 5) Washilah ad-Dakwah (Media Dakwah).

Adapun tujuan dakwah itu dibagi dua yaitu tujuan jangka pendek dan tujuan jangka panjang. Tujuan jangka pendek yang dimaksud adalah agar manusia mematuhi ajaran Allah dan Rasull-Nya dalam kehidupan keseharian, sehingga tercipta manusia yang berakhlak mulia, dan tercapainya individu yang baik (khoiru al-fardiyah), keluarga yang sakinah/harmonis (khoiru al-uhsrah), komunitas yang tangguh (khoiru aljama'ah), masyarakat madani/civil society (khoiru al-ummah) dan pada akhirnya akan membentuk bangsa yang sejahtera dan maju (khoiru albaldah) atau dalam istilah yang disebut dalam Al-Quran yaitu Baldatun thoyyibatun wa robbun ghofur (Saputra, 2012: 9).

Pesan dakwah adalah pesan atau syariat sebagai kebenaran hakiki yang datang dari Allah melalui malaikat jibril kepada para nabi-Nya, nabi Muhammad saw. Pesan dakwah ini dalam al-quran diungkapkan dengan term yang beraneka ragam yang menunjukan fungsi kandungan ajaran-Nya misalnya dalam Q.S. An-nahl : 125, disebut dengan sabili rabbika (Jalan Tuhanmu) (Sambas 1999 : 55).

Pesan dakwah terdiri dari dua kata berbeda yang memiliki definisi berbeda pula, seperti yang sudah dijelaskan sebelumnya, pesan berarti sebuah gagasan atau pikiran yang disampaikan komunikator kepada komunikan. Sedangkan dakwah adalah panggilan, seruan atau ajakan.

Berdasarkan penjelasaan di atas, maka dapat disimpulkan bahwa 
pesan dakwah adalah sebuah gagasan atau pikiran yang disampaikan oleh komunikan kepada komunikator serta didalamnya terdapat muatan dakwah.

Adat istiadat merupakan kebiasaan-kebiasaan sosial yang sejak lama ada dalam masyaakat dengan maksud mengatur tata tertib ataupun sopan santun. Keberadaan manusia yang merupakan bagian dari masyarakat sebagai makhluk individu, makhluk sosial, makhluk berteknologi, juga merupakan makhluk berbudaya, mempertegas bahwa dalam kehidupan bermasyarakat kebudayaan menjadi sarana untuk menyampaikan pesan dakwah. Dilihat dari sudut bahasa Indonesia, kebudayaan berasal dari bahasa sansekerta "buddhayah", yaitu bentuk jamak dari budi atau akal. Pendapat lain mengatakan, bahwa "budaya" adalah sebagai suatu perkembangan dari kata majemuk budi-daya, yang berarti daya dari budi, karena itu mereka membedakan antara budaya dengan kebudayan. Budaya adalah daya dari budi yang berupa cipta, karsa, dan rasa, dan kebudayaan adalah hasil dari cipta, karsa dan rasa tersebut (Widagho, 1994 : 18).

Menurut Teori Interaksi Simbolik, kehidupan sosial pada dasarnya adalah interaksi manusia yang menggunakan simbol-simbol, mereka tertarik pada cara manusia menggunakan simbol-simbol yang mempresentasikan apa yang mereka maksudkan untuk berkomunikasi dengan sesamanya. Dan juga pengaruh yang= ditimbulkan dari penafsiran simbol-simbol tersebut terhadap perilaku pihak-pihak yang terlihat dalam interaksi sosial (Berger, 2004 : 14).

Upacara adat Ngeuyenk Seureub adalah sebuah wasiat atau pesan yang disampaikan melalui benda-benda atau media oleh pangeuyeuk kepada kedua mempelai. Kata Ngeuyeuk Seureuh berasal dari paheuyeuk-heuyeuk yang berarti mengolah atau mengatur rumah tangga. Maksud dan tujuan dari upacara adat Ngeuyeuk Seureub yaitu untuk memberikan pepeling atau nasihat kepada kedua calon mempelai, selain itu Ngeuyenk Seureuh juga dipercaya sebagai pengikat tali batin antara kedua mempelai. Menurut tokoh adat di Kampung palintang yaitu Yuyu, Ngeuyeuk Seureub sebenarnya adalah dakwah, tetapi terdapat perbedaan dengan dakwah pada umumnya yaitu dakwah yang dilakukan adalah menyampaikan makna dan maksud dari benda-benda yang ada pada media upacara adat Ngeuyeuk Seureuh.

\section{HASIL DAN PEMBAHASAN}

Desa Cipanjalu Kecamatan Cilengkrang terletak di dataran tinggi Kabupaten Bandung. Pada umumnya semua wilayah di Desa Cipanjalu 
terdiri atas dataran tinggi yang subur, sangat baik dan cocok untuk dijadikan tanah pertanian, perkebunan, dan peternakan. Hal ini terbukti bahwa mayoritas penduduk di Desa Cipanjalu adalah seorang petani. Selain itu juga terdapat beberapa peternak seperti peternak kambing, ayam kampung, dan sapi. Luas Desa Cipanjalu adalah 2018,463 ha, yang terdiri dari pemukiman, persawahan, sekolah, tempat ibadah, dan pertanian atau perkebunan. Desa Cipanjalu terletak pada radius $5 \mathrm{~km}$ dari pusat pemerintahan kecamatan, $45 \mathrm{~km}$ dari pusat pemerintahan kabupaten, dan $25 \mathrm{~km}$ dari pusat pemerintahan provinsi. Selain itu, Desa Cipanjalu berada di perbatasan daerah Kabupaten Bandung dan sumedang. Hal ini terbukti bahwa Desa Cipanjalu terletak pada batas wilayah utara Desa Cipunagara Kec Tj Siang Subang / Ds Genteng Kec Tanjung Sari Sumedang, sebelah timur Ds Ciporeat Kec Cilengkrang Bandung /Ds Genteng Kec Tanjung sari Sumedang, sebalah barat Ds Melatiwangi Kec Cilengkrang Bandung / Ds Sunten Jaya Kec Lembang $\mathrm{KBB}$, dan sebelah selatan Kel Pasirjati KecUjungberung - Kel Pasirjati Kec Ujungberung Kota Bandung.

Desa cipanjalu memiliki jumlah penduduk yang cukup banyak, baik Secara umum, berdasarkan Usia, Mata pencaharian, dan Pendidikan. Berdasarkan data kependudukan yang diperoleh dari kantor pemerintah Desa Cipanjalu yang tercantum pada data monografi, Desa Cipanjalu memiliki jumlah penduduk 3018 orang yang terdiri dari laki-laki, dan 2746 orang yang terdiri dari wanita. Mayoritas masyarakat Desa Cipanjalu adalah seorang petani. Selain bermata pencaharian petani, masyarakat di Desa Cipanjalu juga ada yang bermata perncaharian sebagai buruh tani, pedagang, guru, pegawai negeri sipil, penjahit, dan sebagainya, namun dari banyaknya jenis mata pencaharian yang sudah disebutkan mayoritas penduduk lebih memilih menjadi seorang petani karena tanahnya yang subur dan sangat cocok untuk bertani. Produktifitas dari beberapa jenis mata pencaharian di atas pada umumnya cukup berhasil, khususnya pada bidang pertanian. Selain itu pemasaran akan produknya pun terbilang baik, hal ini terbukti dengan mudahnya para petani atau peternak menjual produknya kepara pengepul atau Bandar. Namun di balik semua itu terdapat kesulitan pada pengambilan dan pengiriman barang atau produk dari masyrakat, hal ini dikarenakan jarak desa yang cukup jauh dari perkotaan, selain itu khususnya di kampung Palintang sangat susah kendaraan umum dan jaringan. Hasil dari mata pencaharian masyarakat sangat terlihat, hal ini terbukti dengan masyarakat semakin maju dan 
berkembang yang sesuai pula dengan perkembangan zaman.

Berdasarkan hasil observasi ke lapangan, perhatian masyarakat terhadap pendidikan sangat baik. Hal ini terbukti bahawa di wilayah Desa Cipanjalu terdapat Madrash, PAUD atau Taman Kanak-kanak, Sekolah Dasar dan Sekolah Menengah Pertama. Walaupun lembaga pendidikan yang terdapat di Desa Cipanjalu hanya sampai jenjang Sekolah Menengah Pertama, masyarakat Desa Cipanjalu banyak yang inisiatif melanjutkan sekolahnya ke jenjang yang lebih atas, bahkan sudah banyak yang melanujtkan pada tingkat Universitas. Hal ini membuktikan masyarakat Desa Cipanjalu sadar bahwa ilmu dan pendidikan sangatlah penting bagi mereka. Berdasarkan data yang diperoleh dari kantor pemerintah Desa Cipanjalu yang tercantum pada data monografi, mayoritas masyakat Desa Cipanjalu memeluk Agama Islam, namun juga terdapat 2 kepala keluarga yang memeluk Agama non Muslim yaitu Agama Kristen dan Khatolik. Walaupun terdapat perbedaan keyakinan, masyarakat tetap rukun, baik, dan adil. Selain itu kegiatan keagamaan di Desa Cipanjalu sangat baik, hal ini terbukti bahwa terdapat jadwal pengajian bagi ibu-ibu dan anak-anak hingga remaja disetiap minggunya. Selain padatnya jadwal pengajian, masyarakat juga selalu melaksanakan ibadah puasa, shalat Jum'at, Zakat, dan yang lainnya sebagaimana mestinya, walaupun masih terdapat masyarakat yang lalai akan ibadah.

\section{Bentuk Upacara Adat Ngeuyeuk Seureuh}

Ngeuyeuk Seureub biasanya dilakukan sehari sebelum hari pernikahan berlangsung. Begitupun dengan waktu pelaksanaannya, biasanya dilaksanakan pada pagi hari atau malam hari di rumah calon mempelai wanita.

Pernikahan merupakan hal yang wajib dilakukan oleh setiap muslim. Namun di tatar Sunda dapat terjadi karena di jodohkan atau karena keinginan sendiri. Selain itu terdapat beberapa adat yang harus dilakukan baik sebelum hari pernikahan atau pada hari pernikahannya. Berikut runtun sebelum hari perkawinan di tatar Sunda: Pertama, neundeun omong dan Ngalamar. Dalam upacara pernikahan di tatar Sunda, hal yang pertama harus dilakukan adalah Neunden Omong, maksudnya adalah menyampaikan maksud dan tujuan calon mempelai pria kepada keluarga beserta calon mempelai wanita bahwa calon mempelai pria ingin memiliki atau menjadikan calon mempelai wanita menjadi istrinya. Namun maksudnya itu hanya disampaikan secara bahasa, yaitu biasanya tanpa memberikan 
alat atau simbol sebagai pengikat. Selain itu neundeun omong biasanya dilakukan oleh calon mempelai pria saja atau orang suruhan tanpa kedua orang tua dari calon mempelai pria dan tidak membawa barang apapun.

Setelah itu, sesudah disampaikan maksud dan tujuannya, baru akan dilakukan kepada tahap selanjutnya yaitu Ngalamar (melamar atau meminang). Berbeda dengan Neundeun omong, pada saat ngalamar atau melamar, kedua orang tua dari calon mempelai pria juga ikut hadir mengunjungi keluarga calon mempelai wanita. Hal ini dilakukan untuk mengikat calon mempelai wanita secara resmi. Tidak hanya mengikat calon mempelai wanita saja, dalam ngalamar juga di tentukan hari jadinya pernikahan, dari mulai hari, tanggal, bulan, dan tahun. Selain itu ngalamar biasanya diberikan simbol sebagai tanda bahwa calon mempelai wanita sudah ada yang meminang, umumnya simbol tersebut menggunakan cincin.

Kedua, ngukus. Sebelum dilaksanakannya pernikahan, biasanya disiapkan sebuah sesajen yang pada dasarnya berbahan kemenyan, kelapa muda, beberapa rujak, dan sebagainya. Sesajen itu di berikan doa atau jampe oleh leluhur atau tokoh masyarakat disana dengan tujuan tertentu, hal itu disebut Ngukus. Ngukus tidak bisa dilakukan oleh sembarangan orang dan disembarang tempat, ngukus dilakukan pasti atau harus memiliki tujuan, jika untuk di selamatkan dan dilancarkan pernikahan maka tujuan ngukus harus sesuai dengan upacara yang dilakukan. Selain itu ngukus juga dilakukan oleh orang yang berpengalaman.

Menurut bapak Andi (Wawancara : Bandung, 30 Juni 2017) pada dasarnya hanya sedikit orang yang tahu maksud dari ngukus, namun inti dari ngukus maksudnya adalah untuk mendekatkan manusia kepada yang gaib dengan media ngukus tersebut, terutama dengan harumnya asap kemenyan. Tetapi hal itu sesuai dengan kepercayaan saja, karena untuk mendekatkan diri kepada yang gaib, ada banyak cara yakni tidak hanya ngukus saja.

Menurutnya tujuan ngukus pasti selalu baik, karena pada saat ngukus selalu di awali dengan taud (a'udzubillahi minasyaithan nirrajiim), walaupun setiap orang pada saat ngukus do'anya tidak selalu sama, ngukus tetap memiliki maksud yang sama sesuai dengan tujuan ngukusnya. Berikut do'a ngukus yang sederhana menurut bapak Andi :

A'udzubillabi minassyaitan nirajiim

Bismillabirrabmannirabiim

Mul kukus suma wiwitan 
Z. K. Umam, D. Solahudin, dan H. G. Nuraeni

Wiwitan mula ning iman mula ning syahadat
Drat syahadatna Allah humma dewi pangeran
Gumilang-gumilang mul kukus dewi sandana
Sandana simojang asib
Nyiji rama muja puaji
Kabemang kemang suci
Dilanjutkan syahadat.

Ketiga, nyarang. Saat upacara pernikahan dilakasanakan, tentunya keluarga yang melakukan upacara tersebut pasti ingin diberi kelancaran dari berbagai hal, terutama pada saat musim hujan biasanya dari pihak keluarga yang hajatan suka meminta orang pintar untuk menghentikan turunnya hujan beberapa hari, hal ini di sebut nyarang. Jadi nyarang adalah berdoanya seseorang kepada Allah Swt agar tidak turun hujan selama 1-2 hari atau lebih. Dalam hal ini orang yang melakukan adat nyarang bukan berarti bisa menghentikan, menahan, atau memindahkan hujan, tetapi orang tersebut hanya berdoa dengan beberapa media seperti sesajen, hihid, dan sebagainya. Setelah itu turun hujan atau tidaknya tergantung apa di ijabahnya doa tersebut atau tidak. Selain itu, nyarang biasanya dilakukan 1 hari sebelum upacara hajatan atau pernikahan dilaksanakan.

Media nyarang tentunya tidak jauh berbeda dengan ritual lainnya yaitu selalu ada sesajen, namun dalam hal ini media nyarang di kampung Palintang di tambah dengan hihid, dan air yang disimpan di ember. Makna dari hihid yaitu merupakan simbol doa bahwa harapannya pada saat akan turunnya hujan, hujan tersebut dapat tertiup angin sehingga hujannya tidak jatuh pada lokasi hajatan. Sedangkan air yang disimpan di ember maksudnya adalah sebagai tanda bahwa akan turun atau tidaknya hujan, hal ini dapat dilihat jika air tersebut tidak tumpah, maka tidak akan turun hujan sedangkan jika air tersebut tumpah maka hujan akan turun.

Nyarang juga memiliki pantrangan (larangan), pantrangan (larangan) nyarang yaitu orang yang melakukan nyarang maka tidak di perbolehkan mandi, karena jika mandi usahanya akan sia-sia yakni akan terjadinya turunnya hujan. Selain itu pantrangan tersebut biasanya juga berlaku untuk pihak keluarga yang hajatan.

Keempat, siraman. Siraman adalah prosesi menyiramkan air kembang mulai dari ujung kepala calon mempelai wanita hingga ujung kaki. Siraman biasanya dilaksanakan sehari sebelum hari pernikahan yang lazimnya dilakukan pada pagi hari atau siang hari. 
Sebelum dilaksanakan upacara adat Ngeuyeuk Seureuh, terdapat beberapa tahap yang harus di lakukan, yaitu sebagai berikut: Pertama, mempersiapkan media Ngeuyenk. Seureuh. Media atau alat-alat Ngenyeuk Seureuh wajib ada, karena melalui media tersebut pangeuyeuk menafsirkan media ngeyeuk seureh menjadi wasiat atau pesan untuk kedua calon mempelai. Maka dari itu, terlebih dahulu yang harus dipersiapkan adalah alat-alat atau media Ngenyenk Seureuh. Berikut media Ngenyenk Seureuh yang digunakan di kampung Palintang adalah Samak (tikar), kain berwarna putih, empat ikat kayu kecil, empat wadah makanan ringan (kue kering), empat seureuh (sirih) satu ikat, padi satu tangkai, bako (tembakau), halu (penumbuk padi), bedog (Golok), air putih dimasukan ke dalam ruas bambu sebanyak lima ruas, benang, pakaian wanita secukupnya, apu, gambir, pinang, kapol, sisir, kaca, alat kecantikan, samping, empat uang logam.

Kedua, menata atau menyusun media Ngeuyeuk Seureuh. Setelah media Ngenyenk Seureuh terkumpul, maka selanjutnya media itu harus ditata sesuai dengan ketentuan Ngeuyenk. Seureuh di kampung Palintang. Cara menata media Ngeuyeuk. Seureuh dapat dilakukan sebagai berikut: Pertama, Samak (tikar) dan kain putih dihamparkan di tempat yang sudah disiapkan baik di dalam rumah atau di luar rumah. Selanjutnya, empat makanan ringan, empat ikatan kayu, empat uang logam di simpan di tiap sudut Samak (tikar). Setelah itu, seikat daun sirih, bako (tembakau), padi, kaca (cermin), sisir, sepaheun di simpan di tengah tikar. Sedangkan halu, golok, dan air disimpan di samping Samak (tikar). Setelah media tertata atau tersusun sesuai dengan ketentuan, selanjutnya calon pengantin pria dan wanita dipersilahkan duduk bersebelahan di depan pangeuyeuk, dan orang tua calon pengantin duduk disebelah putra putrinya diikuti oleh saudara-saudaranya atau kerabatnya. Setelah semuanya lengkap, kerabat dari kedua belah pihak dipersilahkan untuk membentuk satu lingkaran (mengelilingi media Ngeuyeuk. Seureub), dan selanjutnya upacara adat Ngenyeuk Seureub baru dapat dilaksanakan.

Ketiga, Proses pelakasanaan upacara adat Ngeuyenk Seureuh. Berdasarkan hasil pengamatan langsung dilapangan dan hasil dari wawancara dengan pangeuyeuk. Berikut adalah proses pelaksanaan tradisi Ngeuyenk Seureuh di kampung palintang:

Dalam proses pelaksanaan upacara adat Ngeuyeuk. Seureub hal yang pertama dilakukan adalah diawali dengan membaca do'a oleh ustad atau pangeuyeuk. Setelah membaca do'a selesai, baru dilaksanakan pada upacara 
Ngenyenk Seureuh yaitu pangeuyeuk membuka acara yang kemudian dilanjutkan dengan menjabarkan satu per satu media Ngeuyeuk Seureuh kepada calon pengantin (Samak, kain putih,seupaheun, seikat daun sirih, 4 kue kering, 4 uang logam, 4 kayu, baju wanita, kaca, sisir, tembakau atau bako, alat kecantikan, apu, pinang, gambir, kapol, padi).

Selanjutnya pangeuyeuk memberikan golok untuk dipegang oleh kedua calon pengantin (pengantin pria memegang goloknya sedangkan calon pengantin wanita memegang bagian carangka bedog atau sangkar goloknya). Sesudah goloknya dipegang oleh kedua calon mempelai, lalu golok tersebut di cabut dan dimasukan lagi kedalam sangkarnya, kemudian pangeuyeuk menjabarkan maksud dari mencabut dan memasukan golok itu. Setelah itu pangeuyeuk menyuruh ke dua calon pengantin memegang halu untuk di tumbukan sebanyak lima kali dibarengi dengan membaca basmalah disetiap akan mengetukan halu tersebut. setelah selesai pangeuyeuk menjabarkan maksud dari menumbukan halu itu.

Proses selanjutnya adalah pangeuyeuk sedikit menuangkan air (air dalam ruas bambu) yang telah dipersiapkan ke telapak tangan kedua calon pengantin, setelah selesai pangeuyeuk akan menjabarkan makna dari menuangkan air itu. Kemudian, pangeuyeuk akan membentangkan benang yang sudah disiapkan mengelilingi lingkaran upacara adat Ngeuyeuk Seureuh, yang dimulai dari calon pengantin sampai benangnya habis, kemudian kedua ujung benang tersebut diikatkan. Setelah itu, benang yang sudah diikatkan di gulung kembali dan disimpan di atas Samak atau tikar, dan dilanjutkan penjabaran atau penafsiran oleh pangeuyeuk. Selanjutnya semua media Ngenyenk Seureuh di tutupi oleh samping. Kemudian kedua calon pengantin di persilahkan mengambil salah satu media Ngeuyeuk Seureub yang telah di tutupi oleh samping tadi.

Jika hal di atas sudah dilakukan, kemudian pangeuyeuk mempersilahkan pada orang tua dan kerabat kedua calon pengantin untuk memberikan uang kepada calon pengantin (uangnya di simpan di atas media ngeuyek Seureuh atau di atas samping). Tahap terakhir yang dilakukan adalah kedua calon pengantin dipersilahkan untuk membawa seluruh media Ngeuyenk. Seureub kedalam kamar. Selanjutnya di tutup do'a oleh pangeuyek atau ustadz.

Makna simbol media Ngeuyeuk Seureub berdasarkan hasil wawancara dengan Ust. A. Moch Sirojul Mu'minin, Bandung 19 September 2017 yang penulis lakukan, telah terdapat beberapa simbol pada upacara adat 
Ngeuyeuk Seureub yang sudah ditafsirkan dalam bahasa verbal dan disepakati maknanya. Makna simbol pada upacara adat Ngeuyeuk. Seureub diantaranya adalah:

Samak (tikar) diartikan bahwa kedua calon mempelai dan kedua orangtuanya harus Samak-sud (memiliki tujuan yang sama) dengan niat karena Allah, melaksanakan perintahnya yang telah disunnahkan oleh Nabi Muhammad saw. Dengan harapan agar dalam menjalani rumah tangga selalu mendapatkan pertolongan dari Allah Swt. Hal ini sesuai dengan hadist Nabi Muhammad, yang artinya: "barang siapa yang menikah dan menikahkan karena Allah, maka akan mendapatkan pertolongan dari Allah".

Kain berwarna putih diartikan bahwa pernikahan adalah suatu lembaran baru yang suci atau bersih. Kedua calon pengantin harus menjaga agar pernikahannya senantiasa dalam keadaan bersih lahir dan batin.

4 ikat kayu kecil, 4 wadah makanan ringan, 4 Uang logam diartikan calon pengantin pria diharapkan berikhtiar memenuhi kewajiban dalam memberi nafkah dengan mencarinya ke empat empat arah (kaler/utara, kulon/barat, kidul/selatan, wetan/timur). Maksudnya adalah agar calon pengantin pria tidak putus harapan apabila tidak menemukan rijkinya di satu sisi atau satu arah karena masih ada sisi atau arah yang lainnya.

Sakompet daun Seureub (seikat daun sirih). Sakompet daun dalam peribahasa Sunda biasanya selalu diartikan mengarah kepada sebuah kesalahan. Karena hal tersebut, maka maksud dari sakompet daun Seureuh adalah seandainya ada kesalahan dari calon pengantin, orang tua, atau saudaranya yang dulu ataupun yang sekarang, maka jangan sampai disangkut pautkan satu sama lainnya.

Padi satu tangkai. Sesuai dengan peribahasa bahwa padi semakin berisi semakin menunduk, maka diharapkan apabila dalam menjalani rumah tangga berada dalam kejayaan, maka harus selalu rendah hati.

Bako (tembakau) menurut bahasa Arab bako=baqo berarti abadi. Maka diharapkan pernikahan itu menjadi pernikahan yang pertama dan terakhir, hingga tua dan maut memisahkan keduanya.

Halu (penumbuk padi) diartikan sebagai panggening (pengingat). Dengan diketukan sebanyak lima kali, maksudnya calon mempelai diharapkan selalu mengingatkan satu sama lain terhadap kewajiban ibadahnya yaitu shalat lima waktu.

Golok (golok di pegang oleh calon mempelai pria dan sangkar golok 
di pegang oleh calon mempelai wanita, setelah itu di cabut dan dimasukan kembali). Maksudnya adalah, jika calon mempelai pria mencari nafkah, atau keluar rumah dan sebagainya, maka tempat kembali adalah kepada sang istri, begitupun dengan farji (kemaluan) tidak kepada yang lainnya, dan juga sebaliknya seorang istri adalah milik suami seutuhnya tidak memiliki yang lain.

Air putih dimasukan ke dalam ruas bambu sebanyak 5 ruas sebagai simbol untuk senantiasa bersuci. Diharapkan agar kedua calon pengantin senantiasa menjaga kesucian diri dan keluarga.

Benang (dibentangkan melingkari media Ngeuyeuk Seureub dan diikatkan ujung benangnya) diartikan sebagai simbol tali pengikat kasih sayang suami istri yang tidak ada ujungnya. Sedangkan maksud dari dikelilingkannya benang tersebut menjadikan bahwa kasih sayang tidak hanya kepada pasangannya saja, tetapi juga kepada keluarga dan kerabatnya ataupun dalam segala hal yang berada disekitarnya.

Pakaian wanita secukupnya maksudnya untuk memenuhi kewajiban saling menutupi aurat atau hal-hal yang dianggap memalukan. sehingga calon mempelai pria atau calon mempelai wanita dapat senan tiasa menutup aurat sesuai dengan syariat Islam.

Apu, gambir, pinang, dan kapol setiap bahan masing-masing mempunyai warna dan rasa yang berbeda tetapi apabila disatukan akan menjadi obat dalam bentuk seupaheun yang dapat diartikan bahwa dalam rumah tangga akan banyak cobaan pahit manis yang akan dirasakan oleh kedua pasangan. Maka jika pasangan tersebut mendapatkan hal yang manis atau pahit maka diharapkan dapat saling menguatkan satu sama lain.

Sisir biasanya digunakan untuk merapihkan rambut kusut, maka sisir diartikan apapun masalah yang ada dalam rumah tangga, harus senantiasa dirapihkan oleh kedua pasangan.

Kaca biasanya digunakan untuk bercermin, maka kaca diartikan pasangan suami istri harus senantiasa selalu melihat pada diri sendiri sebelum melihat yang lainnya, terutama pada urusan harta.

Alat kecantikan diartikan sebagai sesuatu yang dapat menambah kecantikan lahir batin. Maka diharapkan kegagahan dan ketampanan suami hanya untuk istrinya, begitupun kecantikan seorang istri hanya di peruntukan bagi suaminya.

Samping artinya mengingatkan bahwa dalam akhir kehidupan jasad suami atau istri akan di tutupi oleh samping. Hal ini juga mengingatkan 
bahwa kehidupan di dunia hanyalah sementara.

\section{Pesan Dakwah pada Upacara Adat Ngeuyeuk Seureuh}

Pesan dakwah yang terdapat dalam acara atau kegiatan upacara adat Ngeuyeuk Seureuh dalam penelitian ini dibagi kedalam dua jenis pesan, diantaranya adalah pesan verbal dan pesan non-verbal.

Pertama, pesan dakwah verbal pada upacara adat Ngeuyeuk Seureuh. Pesan dakwah verbal merupakan pesan dakwah yang disajikan menggunakan seperangkat kata yang telah disusun secara berstruktur sehingga menjadi himpunan kalimat yang mengandung arti. Maka dari itu, peneliti telah menganalisis bahwa pada upacara adat Ngeuyeuk Seureuh terdapat beberapa pesan dakwah verbal yang secara langsung disampaikan oleh pangeuyeuk (da'i) kepada kedua calon pengantin (mad'u).

Pesan dakwah verbal yang terdapat pada upacara adat Ngeuyeuk Seureuh adalah sebagai berikut : 1) Terdapat pada simbol Samak (tikar) yang diartikan bahwa calon pengantin harus memiliki maksud yang sama. Selanjutnya diakhir penafsiran pangeuyeuk menyampaikan hadist yang memiliki arti "barang siapa yang menikah dan menikahkan karena Allah, maka akan mendapatkan pertolongan dari Allah SWT.”; 2) Terdapat pada simbol halu (penumbuk padi) yang dartikan sebagai pengingat, hal tersebut sesuai dengan Q.S at-Tahrim ayat 6; dan 3) Terdapat pada simbol bedog (golok), sesuai dengan Q.S al-Mu'minum ayat 5 - 6 .

Dalam hal ini sudah terbukti bahwa pada upacara adat Ngeuyeuk Seureub di kampung Palintang, memang terdapat nilai-nilai keislaman. Sehingga tradisi ini menurut penulis harus tetap di pertahankan keberadaannya.

Kedua, Pesan dakwah non verbal pada upacara adat Ngeuyeuk Seureuh

Berdasarkan hasil penelitian di lapangan, dari penilaian media upacara adat Ngeuyeuk Seureuh secara eksplisit sudah tergambar ajaran moral yang akan disampaikan oleh pangeuyeuk kepada calon pengantin.

Proses penyelenggaraan tradisi Ngeuyeuk Seureub di kampung Palintang sudah menjadi bukti bahwa pernikahan itu baik. Maka dari itu, upacara adat Ngeuyeuk Seureub yang merupakan salah satu rangkaian pada upacara pernikahan di tatar Sunda memang diyakini telah memiliki nilainilai kebaikan.

Nilai-nilai kebaikan ini dapat dilihat pada media Ngeuyeuk Seureuh yang menjadi simbol kebaikan tersebut. Maka dari itu, upacara adat Ngeuyeuk Seureub telah membeberkan kebaikan-kebaikan yang ada dalam 
kehidupan berumah tangga, kebaikan moral, dan material.

Semua media yang ada pada upacara adat Ngeuyeuk. Seureuh adalah pesan-pesan dakwah non verbal. Berikut adalah pesan dakwah non verbal yang terkandung pada upacara adat Ngeuyeuk Seureub:

Samak (tikar) diartikan bahwa kedua calon mempelai dan kedua orangtuanya harus Samak-sud (memiliki tujuan yang sama) dengan niat karena Allah, melaksanakan perintahnya yang telah disunnahkan oleh Nabi Muhammad saw.

Kain berwarna putih diartikan bahwa pernikahan adalah suatu lembaran baru yang suci atau bersih.

4 ikat kayu kecil, 4 wadah makanan ringan, 4 Uang logam diartikan calon pengantin pria diharapkan berikhtiar memenuhi kewajiban dalam memberi nafkah dengan mencarinya ke empat empat arah (kaler/utara, kulon/barat, kidul/selatan, wetan/timur).

Sakompet daun Seureub (seikat daun sirih). Sakompet daun dalam peribahasa Sunda biasanya selalu diartikan mengarah kepada sebuah kesalahan. Karena hal tersebut, maka maksud dari sakompet daun Seureuh adalah seandainya ada kesalahan dari calon pengantin, orang tua, atau saudaranya yang dulu ataupun yang sekarang, maka jangan sampai disangkut pautkan satu sama lainnya.

Padi satu tangkai. Sesuai dengan peribahasa bahwa padi semakin berisi semakin menunduk, maka diharapkan apabila dalam menjalani rumah tangga berada dalam kejayaan, maka harus selalu rendah hati.

Bako (tembakau) menurut bahasa Arab bako=baqo berarti abadi. Maka diharapkan pernikahan itu menjadi pernikahan yang pertama dan terakhir, hingga tua dan maut memisahkan keduanya.

Halu (penumbuk padi) diartikan sebagai panggening (pengingat). Dengan diketukan sebanyak lima kali, maksudnya calon mempelai diharapkan selalu mengingatkan satu sama lain terhadap kewajiban ibadahnya yaitu shalat lima waktu.

Golok (golok di pegang oleh calon mempelai pria dan sangkar golok di pegang oleh calon mempelai wanita, setelah itu di cabut dan dimasukan kembali). Maksudnya adalah, jika calon mempelai pria mencari nafkah, atau keluar rumah dan sebagainya, maka tempat kembali adalah kepada sang istri, begitupun dengan farii (kemaluan) tidak kepada yang lainnya, dan juga sebaliknya seorang istri adalah milik suami seutuhnya tidak memiliki yang lain.

Air putih dimasukan ke dalam ruas bambu sebanyak 5 ruas sebagai 
simbol untuk senantiasa bersuci.

Benang (dibentangkan melingkari media Ngeuyeuk Seureub dan diikatkan ujung benangnya) diartikan sebagai simbol tali pengikat kasih sayang suami istri yang tidak ada ujungnya. Sedangkan maksud dari dikelilingkannya benang tersebut menjadikan bahwa kasih sayang tidak hanya kepada pasangannya saja, tetapi juga kepada keluarga dan kerabatnya ataupun dalam segala hal yang berada disekitarnya.

Pakaian wanita secukupnya maksudnya untuk memenuhi kewajiban saling menutupi aurat atau hal-hal yang dianggap memalukan.

Apu, gambir, pinang, dan kapol setiap bahan masing-masing mempunyai warna dan rasa yang berbeda tetapi apabila disatukan akan menjadi obat dalam bentuk seupaheun yang dapat diartikan bahwa dalam rumah tangga akan banyak cobaan pahit manis yang akan dirasakan oleh kedua pasangan.

Sisir diartikan apapun masalah yang ada dalam rumah tangga, harus senantiasa dirapihkan oleh kedua pasangan. Kaca (Cermin) diartikan pasangan suami istri harus senantiasa selalu melihat pada diri sendiri sebelum melihat yang lainnya, terutama pada urusan harta.Alat kecantikan diartikan sebagai sesuatu yang dapat menambah kecantikan lahir batin. Samping artinya mengingatkan bahwa kehidupan hanya sementara.

Dalam hal ini sudah terbukti bahwa pada upacara adat Ngeuyeuk Seureub di kampung Palintang, memang terdapat nilai-nilai keislaman. Sehingga tradisi ini menurut penulis harus tetap di pertahankan keberadaannya. Karena selain termasuk kedalam salah satu budaya Sunda, dalam proses dan ala-alat yang digunakan pada acara upcara adat Ngeyeuk Seureub pun memiliki pesan-pesan dakwah.

\section{PENUTUP}

Berdasarkan pada uraian pada hasil analisis penelitian yang telah dipaparkan, maka sesuai dengan hasil penelitian dapat disimpulkan bahwa Pesan dakwah yang terdapat dalam kegiatan ayau acara upacara adat Ngeuyeuk Sereuh di Kampung Palintang, Desa Cipanjalu, Kecamatan Cilengkrang, Kabupaten Bandung adalah sebagai berikut:

Pertama, upacara adat Ngeuyeuk Seureub merupakan salah satu rangkaian upacara adat pernikahan yang ada di tatar Sunda. Ngeuyeuk Seureuh berasal dari kata paheuyeuk-heuyeuk yang berarti mengolah atau mengatur rumah tangga. Ngeuyeuk Seureub di kampung Palintang Desa 
Cipanjalu Kecamatan Cilengkrang Kabupaten Bandung sudah ada sejak tahun 1800-an. Dalam tradisi Ngeuyeuk Seureuh ini, terdapat beberapa benda atau simbol yang memilki makna atau nilai moral yang baik dan berguna bagi kedua calon mempelai pengantin. Karena itu, Ngenyeuk Seureuh memiliki maksud dan tujuan yaitu untuk memberikan pepeling atau nasihat baik kepada kedua calon mempelai pengantin, selain itu Ngeuyeuk Seureuh juga dipercaya sebagai pengikat tali batin antara kedua mempelai. Mengenai waktu dan tempat pelaksanaannya, Ngeuyeuk Seureub biasanya dilaksanakan sehari sebelum hari pernikahan berlangsung, dan tempat pelaksanaannya yaitu dilakukan di rumah mempelai wanita, sedangkan mengenai waktunya biasanya dilakukan pada pagi hari atau malam hari.

Kedua, Dalam kegiatan upacara adat Neuyeuk Seureuh ini terdapat pesan-pesan dakwah Islam. Pesan dakwah pada upacara adat Ngeuyeuk Seureub ini terbagi menjadi dua yaitu pesan dakwah verbal dan non verbal. Pesan dakwah verbal yang terkandung dalam upacara adat Ngeuyeuk Seureub diambil berdasarkan al-qur'an dan hadist, sedangkan pesan dakwah non verbal terdapat pada semua bagian media upacara adat Ngeuyeuk. Seureuh, dalam pemhamannya media tersebut di jelaskan oleh pangeuyeuk atau pemimpin upacara.

Berdasarkan hasil riset, dalam hal ini peneliti memberikan saran yang diharapkan dapat bermanfaat. Saran-saran tersebut diantaranya adalah:

Pertama, karena budaya merupakan hal yang sangat penting bagi bangsa dan Negara, maka upacara adat Ngeuyeuk Seureub harus lebih diperlihatkan kepada masyarakat, khususnya anak-anak. Hal ini harus dilakukan supaya budaya upacara adat ngeuyeuk seureh akan tetap ada, khususnya di tatar Sunda yang semakin berkembangnya zaman budaya semakin di abaikan oleh masyarakat.

Kedua, selain di pertahankannya budaya yang ada, peranan akidah juga diperlukan. Karena dengan adanya aqidah, masyarakat atau siapapun dapat dengan mudah untuk membedakan mana budaya yang menyimpang tanpa ajaran islam, dan budaya mana yang terkandung ajaran-ajaran islam.

Ketiga, Kepada peneliti selanjutnya, disarankan agar meneliti lebih mendalam lagi tentang upaca adat Ngenyeuk. Seureuh di tatar Sunda, baik dari segi sejarah, pengertian, proses pelaksanaannya, sampai kepada pengaruh upacara adat Ngenyeuk. Seureuh terhadap masyarakat. Karena dengan hal tersebut, akan lebih memperjelas apa dan bagaimana upacara adat Ngeuyeuk Seureub itu. 


\section{DAFTAR PUSTAKA}

Arifani, A. (2010) Model pengembangan dakwah berbasis budaya lokal. Ilmu Dakwah: Academic Journal for Homiletic Studies, 4 (15), 849-878.

Berger, A. (2004). Tanda-tanda dalam kebudayaan kontemporer, Yogyakarta: Tiara Wacana.

Gustini, H., \& Alfan, M. (2012). Studi budaya di Indonesia. Bandung: Pustaka Setia.

Romli, A. M. (2003). Jurnalistike dakwah: visi dan misi dakwah bil-qalam, Bandung: Rosda.

Rahmat, J. (2005). Metode penelitian komunikasi. Bandung : Remaja Rosdakarya

Sa'diah, D. (2015). Metode penelitian dakwah. Bandung: Remaja Rosda Karya.

Safei, A. (2003). Memimpin dengan hati yang selesai: Jejak langkah dan pemikiran K.H. Syukriadi Sambas, M.Si, Bandung: Pustaka Setia.

Sambas, S. (1999). Filsafat Dakwah, Bandung: Komini Penerbitan Halaqah Diskusi Dosen (KP-HADID) Fakultas Dakwah.

Saputra, W. (2012). Pengantar ilmu dakwah. Jakarta: Rajawali Pers.

Sugiono. (2006). Metode penelitian kuantitatif kualitatif dan R\&D, Bandung: Alfabeta

Widagho, D. (1994). Ilmu budaya dasar, Jakarta: Bumi Aksara. 